\title{
PI になるまでの道程, 人との出会い
}

難波 康祐

\section{My Own Path in Becoming a Young PI and Meeting Lots of People}

Kosuke Namba

若手 PI として，若手の研究者や学生に伝えたい思い を緅るという本企画の括話をいただいた。若手研究者を エンカレッジする魅力的なメッセージを綴ることは自分 には難しいので，PIになるまでに辿ってきた道のりに ついて振り返ってみたい。PI を目指す皆さんの参考に なる事項があれば幸いである。

\section{研究室配属}

約 23 年前, 大阪市立大学理学部 4 年生になる前の私 は，アカデミアへの道に進むことは全く考えていなかっ た。たた，不真面目な学生生活を過ごしてきたので，研 究室配属後には心を入れ替え実験と勉強に集中する覚悟 であった。配属先研究室には, 単純にものづくりが好き だったことから有機合成化学の部屋を志望した。そこで 磯江幸彦教授 (大阪市立大学名誉教授)の研究室を訪問し たところ，磯江先生はその年で退官されるため，後任の 大船泰史先生 (大阪市立大学名誉教授)の説明をしてくた さった。磯江先生は，「とにかく凄い先生が来てくださ る! その先生に付けば世界トップレベルの研究ができ る!」と大船先生の素晴らしさを力説された。有機化学 の研究室は他にも幾つかあったが, この時点で志望研究 室をここに決めた。今となっては単純な学生だったなと 思うが，先に述べたように研究室配属にはそれなりの覚 悟を持っていたし，どうせならば世界トップレベルと評 される先生に師事したいと思ったのである。だが，定員 2 名のところに, 一緒に見学に行った 3 人全員がこの研 究室を志望し誰も譲らない。そこで, 何とか 3 人とも入 れてもらえないか磯江先生にもう一度掛け合ってみたと ころ，可哀想たから 3 人取ると言ってくたささった。後で 聞いた話だが, 磯江先生は在籍学生の人数を数え間違え

徳島大学大学院医歯薬学研究部 (770-8505 徳島市庄町 1-78-1) Institutes of Biomedical Sciences and Graduate School of Pharmaceutical Sciences, Tokushima University(Tokushima 770-8505, Japan)
て一人多く取っても大丈夫と思われたそうである。何は ともあれ, 磯江先生の数え間違いが無ければ, 一番成績 の悪かった私が有機以外の研究室に行っていた可能性が 高く, 少なくとも今このようなメッセージを書くような ことは無かったであろう。人生は偶然の上に成り立って いると思う出来事である。

\section{大学院生時代}

配属後, 最初の師匠となる大船泰史先生に師事するこ ととなった。大船先生は厳しくて怖い先生だと多くの先 生から聞かされたが，実際には怖いと感じたことはな く, いつも辛抱強く学生が結果を出すのを待ってくだ さっていたように思う。厳しいと覚悟して入った研究室 ではあったが, 実際のところはかなり楽しかった。優秀 で個性豊かな先輩達に囲まれ，夜遅くまで実験すること も全く苦にならなかった。今となって思うのは, 研究室 選びには就職や雲囲気など様々な要素があると思うが, 一番大事なことはやはり学問として自分が面白いと思え る分野に進むことであろう。日々の実験や勉強が苦行と なるようでは絶対に長続きしない。その後, 今後の研究 者にはドクターは必須だと思い博士課程に進学した。博 士課程では，先のことは深く考えずに，とにかく全合成 を達成すること，より専門知識を深めることに専念し た。日本学術振興会の特別研究員 (DC2)に採択されたの で，学位取得後にPDに切り替え留学することにした。 当時付き合っていた彼女と結婚し，そのまま一緒にアメ リカに渡った。やはり先のことは深く考えていなかった が，とりあえずアメリカで成果を出すことのみを考え た。

\section{留学 時代}

最初の留学先は大船先生の紹介でコロラド州立大学の R. M. Williams 教授の研究室にお世話になった。コロラ ドでは長女が誕生し充実した生活であった。パーマネン ト職に就いてもいない状態で子供ができた訳だが，任期 
終了後には何処かに就職できる自信はあった。なので, 先の心配はせずに今できることをやろうと決めた。2 年 近くが経ったとき，製薬企業から来ていた方に会社を紹 介してくれないかお願いしたところ，その方は快く引き 受けてくださった。すぐに人事部に履歴書を送るように 言われたので，準備をしていたところ Williams 教授に 呼び出され, ハーバード大学の岸義人先生のところに行 くことを勧められた。Williams 教授に呼び出されるの がもう少し遅ければまた別の道に進んでいたであろう。 そこで研究の場所を岸研へと移すことになった。岸先生 とは毎日数時間おきにディスカッションを行った。超一 流の先生との毎日のディスカッションは本当に勉強に なった。気が付けば実験の進め方や問題の解決法など多 くのことを学んでいた。この頃は夜寝ていても実験をし ている夢ばかりを見た。まさに寝ても覚めても実験をし ているような感覚だった。ただ, 夢の中で思いついたア イデアが現実で成功すれば格好良かったのであるが, 夢 の中のアイデアが上手く行ったことは一つもない。岸研 生活での終盤には結果が出たので, 晴れて日本に帰国す ることができた。岸先生からは, どんなに困難な研究 テーマであっても強い精神を持って取り組めば道は必ず 拓けることを学んだ。

\section{助 教 時 代}

4 年半もポスドクを続けた結果, アカデミアで自分の 力を試したいと思い始め, 楠本正一先生が所長を務めて おられたサントリー生物有機科学研究所 (生有研)に入所 させていただいた。ここで, 村田佳子博士と共同で始め たムギネ酸の研究は, 現在も当研究室の主要テーマの一 つとなっている。しばらくして, 徳島文理大学の西沢麦 夫先生が助手に来ないかと誘ってくださった。西沢先生 は計 3 回も大阪まで来てくださり, 研究について熱く 語ってくたさった。こうして西沢先生の熱意に惹かれ西 沢研に加わることになった。結果, 生有研を 1 年で退職 することになり，生有研には不義理をしてしまった。そ れにもかかわらず, 生有研の方々とは現在も良好な関係 が続いており, 彼(女)らの懷の深さには今も大変感謝し ている。西沢研での助教時代は私の研究者人生の中でも 楽しい時間であった。西沢先生に何人かの学生を任せて いただいたので, 初めて複数の研究テーマを同時並行で 走らせることができた。助教で雑用も少なかったので, 明るく元気な学生達と共に様々な研究内容で一喜一憂し た楽しい時であった。しかし，この時には少しばかりの 挫折も味わった。助教になったばかりの先生は皆同じこ とを思うはずであるが，思ったように合成が進まない。 自分だったら 3 日で終わるはずの合成が, 学生にやらせ ると 1 カ月以上掛かってしまったりする。この問題は, 学生一人一人に徹底的に貼り付き全ての実験操作を事細
かく指示することで解決した。使う出発原料の量や反応 条件を細かく指示し, TLCを全てチェックし, 反応を 止めるタイミングから精製の条件まで, その都度全て細 かく指示を出し続け, 学生が今何をやっているかを完全 に把握した。学生にとっては迷惑な話だったと思うが, おかげで実験は大幅に遅れることなく進んだし，実験技 術もいち早く向上したと思う。最初は言われることをや るので精一杯だった学生も，卒業する頃には自信が付き しっかりした学生になっていた。

一方，この頃に教員として反省すべきことがあった。 学部 4 年生が行った合成研究をまとめて論文投稿したと ころ rejectされた。内容的には acceptに值するもの だったと思うので, これは私の書き方が良くなかったこ とに他ならない。学生は日々献身的に朝から夜まで本当 に良く頑張ってくれた。それが私の書き方が悪かったせ いで, 彼らの頑張りが正しく評価されないことになって しまった。これには心から反省した。十分に練り直して 再投稿したところ，より IF の高い論文に通すことがで きた。学生の多大な努力を活かすも殺すも教員の心がけ 次第であるということが身に染みた。以後, PIになる まで論文投稿は連勝し続けた。しかし，PIになってか らは rejectされることも増えて来た，もう一度気持ち を引き締め直したい。

\section{講師・准教授時代}

6 年制一本になった薬学部の研究環境は想像以上に厳 しくなっており, 西沢先生から北大谷野研の公募に出す ことを勧められた。「4 年制のままだったら絶対に行か せんかったけどな」と寂しそうに笑っておられたのが今 でも忘れられない。1 年半で西沢研を後にして, 北大の 谷野圭持先生の研究室に講師として移動した。2人の文 理大生が一緒に北大の大学院を受験してくれたので, 西 沢研で立ち上げたテーマをそのまま北大で継続すること ができた。化学オタクの異名を持つ谷野先生の知識量に は圧倒されたが, 谷野先生と有機化学の話をするのはと ても楽しかった。また, 谷野先生は講義やプレゼンが非 常に上手で本当に勉強になった。 1 年目は谷野先生の講 義を毎週聴講して勉強し, 学会発表の際にはスライドの 作成法など多くのご指導をいただいた。現在でもプレゼ ンを襄めていただくことがたまにあるが，私のプレゼン は谷野先生から学んだことがベースである。学生の指導 は今まで通り, 徹底的に細かく指示する方法を踏襲して いたが，そのうち放っておいても結果を出すようになっ て行った。5 年目の頃に, 谷野先生から宍戸宏造先生 (徳島大薬)の後任ポストに応募することを勧めていたた いた。PIへの応募はまだまだ先と思っていたが，それ ならばと応募した。結果, 谷野研をちょうど 5 年で後に することになった。 


\section{現 在}

PI になってから既に 5 年が経過したが，とにかく忙 しい。以前のように細やかに学生の実験を指導できなく なってしまったので, この役割は助教の中山淳博士, Karanjit Sangita 博士に譲り, 今では学生が自ら成長し 結果を出すことを辛抱強く待っている。きっと大船先生 もそうだったのであろう。学部 4 年の時から 23 年経っ た今，ようやく先生方の気持ちがわかって来た。

\section{おわりに}

振り返ってみると, これまでの道程は偶然や運，お世 話になった先生方の導き，仲間の支援によって成り立っ ている。従って，いくら綿密に将来の計画を練ったとこ ろで, 計画通り進むことはなかったであろう。ならば, 先のことをあれこれ考えても仕方がない。今やるべきこ とにしっかりと集中して取り組めば，自然と周りの協力 が得られ道が拓ける。もちろん，協力を得るためには， 常日頃からの礼節が重要であることは言うまでもない。 また，巡って来るチャンスは一瞬である。物怖じせずに すぐさま飛び込む勇気も道を拓くための重要な要素だと 思う。

(2018 年 5 月 11 日受理)
PROFILE

難波康祐 徳島大学大学院医歯薬学研究部・ 教授, 徳島大学副理事

〔経歴〕大阪市立大学大学院理学研究科後期 博士課程修了。〔専門〕有機合成化学，ヶミ カルバイオロジー。〔連絡先〕 e-mail: namba@tokushima-u.ac.jp 